\section{Supplier Services and Their Importance to Floral Retailers in the Midwestern United States}

\author{
Thomas L. Prince ${ }^{1}$, Harry K. Tayama ${ }^{2}$, and John R. Grabner, Jr. ${ }^{3}$ \\ Department of Horticulture, Ohio Agricultural Research and \\ Development Center, The Ohio State University, Columbus, OH 43210 \\ Additional index words. marketing, mass market, wholesale florist, distribution
}

\begin{abstract}
Survey analysis of retail florists in the midwestern United States and floral mass marketers, nationally, identified 18 major services provided by floral suppliers for their retail customers and quantified the retailers' perceived importance of the services. Product quality maintenance, order/delivery reliability, product availability, response to problems, and personnel courtesy were rated by retailers as the five most important services provided by floral suppliers. Retail florists viewed the importance of the 18 services with primary and secondary concerns, whereas mass marketers largely viewed the services as equally important. Mass marketers perceived services related to product marketing, packaging, labeling, and communication/order information services with greater importance than retail florists. The service profiles provide floral suppliers with market information to develop more effective service programs targeted for specific customer segments.
\end{abstract}

The U.S. economy is experiencing a transition from production orientation to service (Cowell, 1984). With today's highly competitive and international business climate, customer service has seen a rebirth in interest and concern in American businesses (Shapiro, 1984; Sharman, 1984; LaLonde et al., 1988). Awareness of service and its importance in the current and future economic en-

Received for publication 3 Mar. 1989. Salaries and research support provided by state and federal funds appropriated to the Ohio Agricultural Research and Development Center, The Ohio State Univ. Approved for publication as manuscript no. 40-89 of the Ohio Agricultural Research and Development Center, Wooster, $\mathrm{OH}$ 44691. The cost of publishing this paper was defrayed in part by the payment of page charges. Under postal regulations, this paper therefore must be hereby marked advertsement solely to indicate this fact.

${ }^{1}$ Postdoctoral Fellow.

${ }^{2}$ Professor of Horticulture.

${ }^{3}$ Associate Professor, Faculty of Marketing, College of Business, The Ohio State University, 1775 College Rd., Columbus, OH 43210. vironment led to the initiation of this study to examine customer service in the floral industry.

Services within the floricultural channels of distribution represent a major share of marketing costs among producers, wholesalers, and retailers (Goodrich, 1980; Sullivan et al., 1980). Customer service comprises, in addition to the product, activities provided by a supplier to a customer with the purpose of gaining repeat sales (Hopkins and Bailey, 1970). Customer service forms the interface between sellers and buyers in the distribution channel and forms the basis for market transactions and distribution strategy (LaLonde, 1985). However, effective communication of desired services among growers, shippers, wholesalers, and floral retailers is sometimes lacking, and this lack often results in less than ideal service performance (Prince, 1985a, 1985b). The end result is that floral suppliers may lose their competitive position in the global marketplace, not only because of inferior product quality, but also because they fail to offer the required services or provide the excellence in service associated with a quality product.

The first research objective was to identify and describe the types of services performed among floral suppliers (wholesale florists, wholesale growers, and shippers) for their customers (florists and mass marketers), with a second objective to quantify the level of importance retail florists and mass marketers place on the services provided by their suppliers. Development of this management information may allow suppliers to focus their service programs on activities considered most important by their customers, thereby improving distribution effectiveness.

Telephone and personal interviews with selected members of the production, shipping, wholesaling, and retailing segments of the floriculture industry were used to obtain information on the types of service activities performed in floral distribution (Prince, 1989). Also, group discussions relative to customer service were conducted with industry representatives throughout the United States. These groups met while attending the 1986 and 1987 Ohio Florist Short Course and the 1987 Wholesale Florists and Florist Suppliers of America Management Institute in Columbus, Ohio. The next step was the development of a structured questionnaire and the collection of survey data from random samples of retail florists and floral mass market operations obtained from membership lists of Florists' Transworld Delivery, the Society of American Florists, Florafax Association International, and the Produce Marketing Association

Questionnaires were pretested and modified before their distribution to managers of retail florist businesses in 12 midwestem states (including Ohio, Indiana, Missouri, Kansas, and the states to their north) and floral buyers of floral mass market operations, nationally, during May through July 1988. Seven-point rating scales were used in the questionnaire format to reduce the burden on respondents and to minimize random variation in responses (Cox, 1980).

A total of 511 surveys were returned from the retail florist sample, which represented a $25 \%$ response rate; 502 surveys were fully completed and usable for statistical analysis. Thirty-eight surveys were returned from the mass market sample, resulting in a $29 \%$ re- 
Table 1. Description of 18 components of customer service provided by floral suppliers to retai florists and floral mass market operations.

\begin{tabular}{|c|c|}
\hline $\begin{array}{l}\text { Service } \\
\text { component }\end{array}$ & Description \\
\hline Delivery speed & $\begin{array}{l}\text { Amount of time expended from the moment of order placement to order receipt. } \\
\text { Includes time required to process an order and response time to deliver the } \\
\text { product. }\end{array}$ \\
\hline $\begin{array}{l}\text { Product } \\
\text { availability }\end{array}$ & $\begin{array}{l}\text { product. } \\
\text { types of floral products throughout the year, and availability of new and unique } \\
\text { floral products. }\end{array}$ \\
\hline $\begin{array}{l}\text { Response to } \\
\text { problems }\end{array}$ & $\begin{array}{l}\text { Readiness and ability to correct problems and errors, to offer solutions and al- } \\
\text { ternatives, and to provide fairness in the handling of claims. }\end{array}$ \\
\hline $\begin{array}{l}\text { Product } \\
\text { quality } \\
\text { maintenance }\end{array}$ & $\begin{array}{l}\text { Providing product at the optimum stage of flower harvest and using proper post- } \\
\text { production treatments to maximize flower quality and freshness of product. }\end{array}$ \\
\hline $\begin{array}{l}\text { Product } \\
\text { pricing/ } \\
\text { discounts }\end{array}$ & $\begin{array}{l}\text { Provision of pricing discounts during oversupply periods, discounts for early cash } \\
\text { payments, discounts for large quantity purchases, and an overall competitive } \\
\text { pricing structure for all products. }\end{array}$ \\
\hline $\begin{array}{l}\text { Order/delivery } \\
\text { reliability }\end{array}$ & $\begin{array}{l}\text { Providing consistency in delivery and order-taking throughout the year, i.e., on- } \\
\text { time delivery and accurate order taking. }\end{array}$ \\
\hline Credit policy & \\
\hline $\begin{array}{l}\text { Post-sale } \\
\text { support/ } \\
\text { guarantees }\end{array}$ & $\begin{array}{l}\text { Provision of flexible creall polices } \\
\text { Provision of post-sal }{ }^{1} \text {. assistance and product guarantees. }\end{array}$ \\
\hline $\begin{array}{l}\text { Product } \\
\text { knowledge }\end{array}$ & $\begin{array}{l}\text { Providing a sales force with a thorough knowledge of floral products, including } \\
\text { knowledge of product cultivars, postproduction handling procedures, product } \\
\text { uses, and product trends. }\end{array}$ \\
\hline Accessibility & $\begin{array}{l}\text { uses, and product trenas. } \\
\text { Ease of contact with supplier personnel in authority and ease of placing orders. } \\
\text { Provision of extended business hours during holidays, toll-free telephone num- } \\
\text { ber, and telephone answering machine during nonbusiness hours. }\end{array}$ \\
\hline $\begin{array}{l}\text { Order/delivery } \\
\text { flexibility }\end{array}$ & $\begin{array}{l}\text { Ability to go beyond the normal business routine to satisfy customers, i.e., ac- } \\
\text { commodating last-minute changes in orders/delivery, making deliveries at a } \\
\text { specific time of day, facilitating customized orders. }\end{array}$ \\
\hline $\begin{array}{l}\text { Promotional/ } \\
\text { marketing } \\
\text { support }\end{array}$ & $\begin{array}{l}\text { Providing support to industry advertising programs. Provision of promotional } \\
\text { literature, in-store point-of-purchase merchandising aids, and cooperative as- } \\
\text { sistance in promotional planning and marketing. }\end{array}$ \\
\hline $\begin{array}{l}\text { Product } \\
\text { packaging }\end{array}$ & Providing packaging of floral products that minimizes product damage in transit. \\
\hline $\begin{array}{l}\text { Personnel } \\
\text { courtesy }\end{array}$ & $\begin{array}{l}\text { Providing a sales force that is friendly, courteous, and understanding, and one } \\
\text { that has empathy for customer satisfaction. }\end{array}$ \\
\hline $\begin{array}{l}\text { Product } \\
\text { labeling }\end{array}$ & $\begin{array}{l}\text { Provision of accurate and legible container and tag labeling of product variety, } \\
\text { quantity, and/or size. Providing bar coding of floral products. }\end{array}$ \\
\hline $\begin{array}{l}\text { Communication/ } \\
\text { order } \\
\text { information }\end{array}$ & $\begin{array}{l}\text { Provision of prompt order status information, prompt communication of order } \\
\text { changes and delays in shipping. Keeping the customer fully informed. }\end{array}$ \\
\hline $\begin{array}{l}\text { Relationships/ } \\
\text { contractual } \\
\text { arrangements }\end{array}$ & $\begin{array}{l}\text { Ability and willingness to build long-standing business relationships, commit- } \\
\text { ment, and trust between supplier and customer. Developing standing-order } \\
\text { policies that benefit both parties. }\end{array}$ \\
\hline $\begin{array}{l}\text { Box } \\
\text { standardization }\end{array}$ & $\begin{array}{l}\text { Provision of boxing standards and enforcing standards in the containerization of } \\
\text { floral products. }\end{array}$ \\
\hline
\end{tabular}

sponse rate; all were fully completed and usable for statistical analysis. Analysis using Cronbach's alpha coefficient (Cronbach, 1951) indicated that questionnaire items relative to service achieved acceptable reliability. Data analysis comprised frequency distributions relative to business characteristics of respondents and mean comparisons of service importance ratings between the two respondent groups.

Survey bias because of nonrespondents was assessed through a statistical comparison of survey responses from early and late respondents of the survey, and through a random telephone survey sampling of nonrespondents (Miller and Smith, 1983). Results of both tests indicated that nonresponse bias was not a serious threat to the validity of the survey research. Thus, the survey respondents represented the business characteristics, viewpoints, perceptions, and opinions of the general population surveyed. Furthermore, the random sampling of firms from their re- been in business between 6 and 10 years; $32 \%$ between 11 and 30 years; $19 \%$ between 31 and 50 years; and another $19 \%$ had floriculture business experience in excess of 50 years. These statistics suggested that the survey respondents generally reflected characteristics of the retail floral industry at large.

The research identified and described 18 components of customer service between supplier and retailer in floral distribution (Table 1). These components revealed the broad scope of customer services performed within the floral industry, as they spanned all elements of the marketing mix, including issues of product, price, promotion, physical distribution of floral products, and business management. This finding suggests that the development of an effective customer service program for suppliers requires input from all facets of the business and should not focus solely on orders, deliveries, and complaint handling.

Service importance ratings. Mean importance ratings aggregated across both samples for the 18 customer service components are provided in Table 2. These ratings are listed in order of greatest to least importance, as perceived by the retailer, and indicate the level of importance placed by retail customers on each component when selecting or evaluating floral suppliers. Suppliers' product quality maintenance, order/delivery reliability, product availability, response to problems, and personnel courtesy were found to be the five most important customer service components. Components of lesser importance included supplier accessibility, postsale support/guarantees, delivery speed, product knowledge, and product pricing/discounts. Of least importance were service components comprising credit policy, product packaging, product labeling, promotional/marketing support, and box standardization. These services were rated lower, but all service components, except box standardization, achieved a mean rating $>4.0$, the midpoint of the importance scale.

The importance ratings indicated that quality of product and the maintenance of product quality by suppliers is the top concern of retailers in the floriculture industry. However, the high ratings of the other services indicated that distribution, marketing, and personnel services have an important role in the overall product/service offerings of floral suppliers. In particular, services relative to order/delivery reliability, product availability, response to problems, personnel courtesy, accessibility, post-sale support, delivery speed, and product knowledge achieved mean importance ratings $>6$ on a 7-point importance scale.

Segmented service importance ratings. In general, the mass market sample rated most service components with the same level of importance, or slightly higher in importance, than the retail florist sample, with nine of the 18 components registering a significantly higher mean importance score. The components relative to product availability, product knowledge, communications/order information, order/delivery flexibility, relationships/ 
Table 2. Mean importance ratings for 18 customer service components overall and for retail florist (RF) and mass market (MM) samples. ${ }^{\mathrm{z}}$

\begin{tabular}{lccc}
\hline \hline Service component & Overall & RF & MM \\
\hline Production quality maintenance & 6.9 & 6.9 & 6.9 \\
Order/delivery reliability & 6.6 & 6.6 & 6.8 \\
Product availability & 6.5 & 6.5 & $6.7^{*}$ \\
Response to problems & 6.4 & 6.4 & 6.6 \\
Personnel courtesy & 6.3 & 6.3 & 6.4 \\
Accessibility & 6.2 & 6.2 & 6.4 \\
Post-sale support & 6.1 & 6.1 & 6.2 \\
Delivery speed & 6.1 & 6.1 & 6.3 \\
Product knowledge & 6.1 & 6.0 & $6.5^{*}$ \\
Product pricing/discounts & 5.9 & 5.9 & $5.7^{*}$ \\
Communications/information & 5.8 & 5.8 & $6.5^{* *}$ \\
Order/delivery flexibility & 5.8 & 5.7 & $6.2^{*}$ \\
Relationships/contracts & 5.7 & 5.7 & $6.2^{*}$ \\
Credit policy & 5.5 & 5.5 & 5.6 \\
Product packaging & 5.5 & 5.5 & $6.4^{* *}$ \\
Product labeling & 5.1 & 4.9 & $6.3^{* *}$ \\
Promotional/marketing support & 4.7 & 4.6 & $5.5^{* *}$ \\
Box standardization & 3.9 & 3.8 & $5.0^{* *}$ \\
\hline
\end{tabular}

'Importance of service when selecting a floral supplier: $1=$ unimportant, $7=$ very important; $\mathrm{n}(\mathrm{RF})$ $=502 . \mathrm{n}(\mathrm{MM})=38$. Significant differences between $\mathrm{RF}$ and $\mathrm{MM}$ by $t$ test at $P=0.05(*)$ and $0.01(* *)$.

contracts, product packaging, product labeling, promotional/marketing support, and box standardization were rated higher in importance by the mass market sample than by the retail florist sample. Only one component, box standardization, was rated lower than 5.5 on the 7-point importance scale for the mass market group.

Ranking the mean importance ratings for the service components also sets apart the florist and mass market groups. The top four services are ranked similar in importance by the two groups, but the mass market group ranked communications/order information as the fifth most important service, while florists ranked it eleventh. These rankings suggest that mass marketers place greater importance on supplier communication/information services than do retail florists.

The importance ratings of the two groups also suggests a distinction in the way both groups view customer service. The retail florists rated service components related to the physical distribution of the goods as of primary importance, while services related to marketing, labeling, boxing, and communication were of lesser importance. The mass market group viewed physical distribution services with high importance and also viewed marketing and communication aspects of customer service with a similar level of im- portance. Thus, retail florists perceived customer service with primary and secondary concerns, but mass marketers had a monolithic perception of service and viewed its components as largely being equally high in importance.

Although the 18 service components define the major activities comprising a customer service program, a supplier's service program might not be limited to these services. The dynamics of the economic and market environment surrounding floricultural businesses require continuous monitoring of customers' needs and identification of new services to satisfy those needs. In addition, suppliers must ascertain relative costs and benefits associated with a given customer service program and evaluate its effectiveness.

For floral suppliers, this research has developed the foundation for adopting a customer service philosophy within the floral industry. This service philosophy comprises a company-wide belief, practice, and policy to consistently satisfy customers. The segmented service profiles may assist suppliers in developing more effective service programs targeted for the needs of retail florists and mass marketers. Floral suppliers can focus their programs on the most salient services and effectively achieve their service goals through the identification of customers' service needs.

In a broader perspective, the customer service philosophy can permeate beyond the supplier-retailer relationships researched in this study to include all members throughout the floral distribution channels, from the producer of seeds, plants, explants, and cuttings to the ultimate consumer. Through open lines of communication between buyers and sellers, a consensus of service strategy throughout the channels can be developed, providing for a continuous value-added process throughout the supply chain. The end result is a more valuable product/service offering for the ultimate consumer and increased consumer satisfaction, possibly leading to an expansion in the market for floral products and services.

\section{Literature Cited}

Cowell, D.W. 1984. The marketing of services. CAM Found., London.

Cox, E. 1980. The optimal number of response alternatives for a scale: A review. J. Marketing Res. 17:407-422.

Cronbach, L.J. 1951. Coefficient alpha and the internal structure of tests. Psychometrika 16:297334.

Goodrich, D.C., Jr. 1980. Floral marketing. Chain Store Publ., New York.

Hopkins, D.S. and E.L. Bailey. 1970. Customer service: A progress report. The Conference Board, New York.

LaLonde, B.J. 1985. Customer service, p. 235256. In: J.F. Robeson (ed.). The distribution handbook. Natl. Council for Physical Distrib. Mgt. The Free Press, New York:

LaLonde, B.J., M.C. Cooner. and T.G. Noordewier. 1988. Customer' service: A management perspective. Council of Logistics Mgt., Oak Brook, Ill.

Miller, L.E. and K.L. Smith. 1983. Handling nonresponse issues. J. Ext. Sept./Oct.:45-50.

Prince, T.L. 1985a. The performance of floral wholesalers. Florists' Rev. 31 Jan.:26-29.

Prince, T.L. 1985b. The shortest distance? Florists' Rev. 14 Mar.:45-53.

Prince, T.L. 1989. Customer service of floriculture suppliers in the Midwestern floral distribution channels: Its relationship to retailer satisfaction and purchasing intention. PhD Diss., The Ohio State Univ., Columbus.

Shapiro, R.D. 1984. Get leverage from logistics. Harvard Business Rev. 62(3):119-126.

Sharman, G. 1984. The rediscovery of logistics. Harvard Business Rev. 62(5):71-79.

Sullivan, G.H., J.L. Robertson, and G.L. Staby. 1980. Management for retail florists. W.H. Freeman, San Francisco. 